\title{
Not-Shakespeare and the Shakespearean Ghost
}

\author{
Peter Kirwan
}

A book with the title The Oxford Handbook of Shakespeare and Performance sets up implicit exclusions from its cover page, in a word with complex and overlapping associations:

'Shakespeare'. This is not a volume about the performances undertaken by an individual called Shakespeare, but performances of the writing performances of William Shakespeare, his dramatic (and perhaps poetic) works. Even at this most basic level, the term 'Shakespeare' is complex: a quarter to a third of the plays to which Shakespeare contributed contain the writing of other dramatists, and, as anyone who has been involved in creating theatre knows, the words of a playtext make up only one part of the whole play/performance of which the written texts are only one type of record. Shakespeare is shorthand for a body of work associated with Shakespeare, an industry spanning four centuries of reworking, rewriting, and reperforming this body, as the other essays in this book make clear.

The instability of 'Shakespeare and/in performance' is already implicit in the seemingly infinite number of collaborative forms which the coupling of those terms makes possible, but this essay seeks to address a broader question: the performance of the wider early modern drama as Shakespearean performance. The overwhelming focus on Shakespeare over his contemporaries in criticism, production, and teaching around the world has led to a situation in which the 'Shakespearean' often stands for much more than Shakespeare. Even in surveying academic book titles, the selling power of Shakespeare's name makes it synecdochic of a playing company (The Shakespeare Company), the theatre industry of his time (The Shakespearean Stage), his place of work (Shakespeare's London), and the art of the early modern stage (The Shakespearean Drama). Just as the 'Shakespearean Sonnet' comes to stand for any sonnet written in the form preferred by Shakespeare, so too 
does 'Shakespearean drama' come to stand for any play written for the early modern stage; and this trend is extended in the UK by the major productions of early modern drama being performed by the Royal Shakespeare Company and Shakespeare's Globe, among other theatres.

Considered thus, the drama of Christopher Marlowe, John Ford, John Webster, and many others - including the sprawling canon of 'Anon' - becomes part of 'Shakespearean drama', an extension to the generally accepted corpus; even Doctor Faustus is, in some sense at least, deemed a Shakespearean tragedy. The common-sense reaction against this is obvious; nevertheless, Marlowe's play is repeatedly framed within a Shakespearean paradigm, interpreted, and read in relation to the 'Shakespearean'. But this is also true if the opposite approach is taken, and the plays of Shakespeare's contemporaries are seen as fundamentally other to Shakespeare. The newly launched Digital Renaissance Editions announces itself thus: 'With its focus on producing peer-reviewed scholarly editions of plays by Shakespeare's immediate predecessors, contemporaries, and successors, the project is dedicated to expanding the range of early English drama available for study, teaching, and performance' ('Home'). The resource's remit is shaped by the vacuum at its chronological heart, filling in the areas around an absent central point of Shakespeare himself. The dissonance between the early modern dramatic canon and Shakespeare is clear elsewhere, as in the subtitle of Pascale Aebischer's book Screening Early Modern Drama: Beyond Shakespeare, but even the sheer volume of books dedicated to the study of 'Shakespeare and His Contemporaries' keeps current the separation of 'and' between Shakespeare and those writers who are not Shakespeare - or 'not-Shakespeare', as I shall refer to the phenomenon (often a seemingly debilitating condition) in this chapter.

'Shakespeare' contains its own opposite. Shakespeare and Not-Shakespeare are a binary, two different sides of a coin that are rigidly demarcated from one another, partly as a 
result of the historical desire to elevate Shakespeare above his contemporaries. As David Farley-Hills notes in an introduction that participates inadvertently in the views it rejects, 'his artistic eminence has led (by false logic) to the view of him as loftily unconcerned with what was going on around him. To think of the Swan of Avon competing with the other birds for the crusts thrown to him by the stinkards has almost become a blasphemy' (1). The absolute distinction between Shakespeare and not-Shakespeare insists particularly that we see the latter for what it is not, or more problematically what it fails to be. Yet if they are two sides of the same coin, the currency is still regularly presented as Shakespearean drama, as in the above titles.

In an attempt to theorize this inherent paradox, in which not-Shakespeare is and is not a form of Shakespearean performance, I invoke two critical models. Susan Bennett's seminal 1996 chapter 'Not Shakespeare: Our Contemporary' establishes the term 'Jacobean' as a particular aesthetic characterized by its opposition to Shakespeare. While this is only one facet of not-Shakespeare, Bennett's model sets out the positive sense by which notShakespeare seeks to utilize its negative determination to positive effect. The second model is Marvin Carlson's work on ghosting, treating the experience of theatre as a continual evocation of memories. Carlson's work has been used to understand the resonances of spaces, actors' bodies, texts, and revivals, but I am interested here in the cover of his book, bearing a photograph of a hand holding up a skull. The allusion to Hamlet is unmistakable and insists that, even in a volume whose subject is not Shakespeare, Shakespeare's ghosting presence is the key pre-existing interpretive lens through which the contents of the book may be uncovered. Carlson's work is usually used to explain resonances that are past, but there is much to be said also for synchronous memory as Shakespeare and not-Shakespeare inform one another mutually. 
This essay seeks to confront the undesirable, but perhaps unavoidable, problem of not-Shakespeare's negatively defined status by unveiling some of the ways in which notShakespeare is treated as part of, or viewed through, a Shakespearean paradigm. I begin with those productions that present not-Shakespeare as Shakespeare - albeit often as an inferior or supplementary example of 'Shakespeare'. I then shift to those that react explicitly against the canonical edifice, which embrace and perform their status as not-Shakespeare. Both approaches consider the productions' own choices in their invocation and exorcism / appropriation of a Shakespearean spirit, but also critical reactions to the productions which use Shakespeare as a framework for articulating the productions' nature. Finally, I return to the disquieting ramifications of this phenomenon for the performance of Shakespeare's own plays, for which the dominant aura of the Shakespearean is as much a shackle as it is for the wider repertory.

\section{Not-Shakespeare as more-Shakespeare}

Although the professional performance of early modern drama is in robust health, with a wide range of mainstream and fringe companies producing an increasing broad repertoire, the main centres for the performance of not-Shakespeare, as demonstrated by Karin Brown's commendable census, are institutions dedicated to the transmission of Shakespeare. In North America these include the American Shakespeare Center and the Shakespeare Festival at Stratford, Ontario; but in the UK, which will be my primary focus here, the bulk of professional productions have emerged from the Royal Shakespeare Company, Shakespeare's Globe and the National Theatre which, although it lacks Shakespeare in its title, states that its mission is 'to procure and increase the appreciation and understanding of the dramatic art in all its forms as a memorial to William Shakespeare' (National Theatre 2). Performance of early modern plays within these institutions is necessarily ghosted by Shakespeare, given that returning audiences are many times more likely to have seen Shakespeare in previous visits to 
these venues than the work of his contemporaries, and that even those visitors attending nonShakespearean plays will (with the exception of the National) see Shakespeare's name plastered across their tickets, programmes, venue signs, and advertising.

The RSC and Globe are, at the time of writing, the main producers of regular seasons of not-Shakespeare in the UK. Under the artistic directorship of Gregory Doran, the RSC's Swan Theatre has been reinstated as a house for the exploration of Elizabethan and Jacobean drama, while the opening of the Sam Wanamaker Playhouse (SWP) at the Globe under Dominic Dromgoole's leadership has enabled that theatre to institute regular seasons of Jacobean and Caroline drama. The importance of not-Shakespeare being in a second(ary) space for both institutions is easy to see. The return of not-Shakespeare to the Swan accompanied Doran's decision to stage every Shakespeare play in the core canon in a major production in the Royal Shakespeare Theatre (RST), meaning that even plays such as King John will be performed on the main stage, creating an obvious hierarchical distinction in which the Swan hosts Shakespeare's contemporaries and commercial inferiors alongside new writing and other revivals. The Globe, meanwhile, despite the obvious opportunity to explore the possibilities of a candlelit playhouse for Shakespeare's later plays, has so far maintained a clear distinction in its productions of early modern drama between Shakespeare in the main theatre and not-Shakespeare in the smaller space, a binary further consolidated by the relocation of the regular Read not Dead playreading series of not-Shakespeare to the SWP. The obvious commercial imperative is to be lamented equally for both restricting the availability of not-Shakespeare (in the Globe's case, to a much smaller and more expensive theatre) and for the relative lack of opportunity to see Shakespeare performed in the more intimate venues.

The relationship is not simply hierarchical, however, but symbiotic. In the summer of 2015, the RSC advertised a season of plays set in Venice, pairing Othello and The Merchant 
of Venice in the RST with Volpone and The Jew of Malta in the Swan. The combination of plays invited audiences to attend multiple productions and make shared meaning between them. The effect was mutually beneficial. [Check verb tenses for consistency. This paragraph has thus far used past tense for the 2015 season; hereafter uses present.] The not-Shakespeare, and presumably more difficult to sell, plays were sold through their close association with Shakespeare, offering more early modern encounters with Venetian commerce, Mediterranean politics, and Jewish antagonists. Simultaneously, audiences were encouraged to return to the more regularly staged Shakespeare plays through the promise of their association with something new; a supplement to Shakespeare promises that, even if you have seen the plays before, 'the latter, less familiar play will illuminate the themes or provide an alternative perspective on the issues raised in the former' (Aebischer and Prince 7). This manifested in this instance both as shared interest (understand The Merchant of Venice better by seeing The Jew of Malta) and as playful inversion; Simon Hedger's Machiavelli began the RSC's The Jew of Malta by bounding on stage wearing a 'Royal Marlowe Company' t-shirt in the style of the RSC's instantly recognizable logo (Smith). The ghosting of these productions with one another was integral to their conceptualisation, generating a collective experience based around shared cultural memories and expectations of both Shakespeare and not-Shakespeare.

Carlson's notion of the haunted stage is rooted in a monodirectional chronological structure that assumes memory of past experiences, "the simultaneous attraction to and fear of the dead, the need continually to rehearse and renegotiate the relationship with memory and the past' (167). The negotiation that happens in the theatrical moment is with past experiences, both those of the audience member and of the theatre itself, through its associations with past performances. Raphael Samuel argues that memory is 'an active, shaping force; that it is dynamic - what it contrives symptomatically to forget is as important 
as what it remembers - and that it is dialectically related to historical thought, rather than being some kind of negative other to it' $(\mathrm{x})$. The ghosting of past productions illustrates the conversation between memory and history that Samuel sees, the present theatrical moment working consciously with the multiple moments shared in the collective memory. However, the model is even more useful when considered synchronically for plays performed alongside one another. This is particularly pertinent to the strategy of cross-play ensemble casting exploited by the RSC, most notably in the 2001-2 and 2006-8 Histories cycles directed by Michael Boyd, where thematic doubling across several productions staged concurrently rewarded the repeat viewer. Coen Heijes offers a commendable taxonomy of doubling in these productions, but limits his reading through a rigid adherence to the operations of memory in the sequence in which the plays were produced (from 1 Henry VI to Henry V) despite the fact that the plays were presented in two different sequences as well as in continual repertoire, and thus could be encountered in a vast number of possible permutations. Ghosting is synchronous as well as retrospective, and means that it is possible to see Malta ghosting Merchant or Merchant ghosting Malta, or both independently of one another, albeit the season advertising makes cross-contamination difficult to avoid entirely.

Elsewhere, I have suggested that this model of ghosting allows for a complex crossfertilization of meanings in a season of not-Shakespeare to extend the possible applications of synchronous memory and compensate for the audience's assumed lack of familiarity with the plays by making the season greater than the sum of its parts (“The Roared-At Boys?"). For the purposes of this essay, the value of ghosting (whether synchronous or linear) is in the establishing of a link between Shakespeare and not-Shakespeare, a link which Aebischer and Prince suggest may emerge as ‘burlesque' or 'recycling' (9). In 1969-1970, Prospect Theatre Company toured Richard II and Edward II with a cross-cast ensemble and Ian McKellen playing both title roles. The National Theatre connected The Revenger's Tragedy and Hamlet 
by casting Rory Kinnear in the lead roles of the Olivier Theatre productions of the two plays in 2008 and 2010 (the order of the productions reversing Vindice's own ghosting of Hamlet), and the RSC had a shared ensemble perform The Taming of the Shrew and The Tamer Tamed in 2003/4 - though in the Stratford-upon-Avon performances, tellingly, the Shakespeare play was performed in the RST, the not-Shakespeare in the Swan. In each instance, the iterated bodies of actors invited thematic comparison but also indelibly linked the two sets of work, yoking them with an aesthetic unity that bridged the chasm between Shakespeare and notShakespeare, at least from the returning audience's point of view. Within such a strategy, Shakespearean ghosting (the more familiar Shakespeare lending interpretive significance to the lesser known play) becomes a means of legitimization; not-Shakespeare becomes an extension of Shakespeare, more-Shakespeare.

The importance of ghosting is perhaps best illustrated in the performance of early modern plays that are the subject of Shakespearean authorship claims. I have written extensively elsewhere about not-Shakespeare as it relates to Shakespeare authorship studies and the plays of the so-called Shakespeare Apocrypha, for which historically it has been acceptable for even mainstream editors to declare a play not-[written-by]-Shakespeare if it is not-[morally/aesthetically/poetically-good-enough-for]-Shakespeare (Apocrypha). The subjective quality of this value judgement is overt, and lingers most overtly in the assumption that authorship can be determined by attending a performance of a disputed play and hearing or sensing the presence of Shakespeare, as if performance offers a quasi-religious access to a truth about a text. These are the plays most overtly defined by the not-Shakespeare status, and in recent years such status has been most important to those plays sharing the name Cardenio or Double Falsehood. The frisson of the 'lost' Shakespeare play has regained theatrical capital since the 2010 publication of Double Falsehood in the Arden Shakespeare (Hammond), and the desire to test an attribution in performance has resulted in several 
amateur and professional productions which have sought their own strategies to make the play Shakespearean. For the amateur London company KDC Theatre in 2010, performing a text closely adherent to Double Falsehood, this came in the form of introducing representations of a Shakespeare-quoting Don Quixote and Sancho Panza as the characters Fabian and Lopez and the inclusion of a Duenna for Leonora based on the Nurse from Romeo and Juliet, allowing the scene of Don Bernard forcing Leonora into an unwanted marriage the more clearly to evoke Capulet's relationship to Juliet and the Nurse. Director Barrie Addenbrooke pointed out that he was directing the play 'as [any other] Shakespeare play', reflecting here the latent understanding that a default performance of an early modern play might as well be Shakespearean (Addenbrooke). For Phil Willmott, directing the same play for MokitaGrit Productions in London the following year, Don Bernard was regendered and Henrique [sic] performed as a privileged Etonian type, here evoking more closely the Lady Capulet and Paris relationship. Elsewhere, the rather dour shepherds of Double Falsehood were reimagined as countryfolk partaking in a sheep-shearing festival, deliberately evoking The Winter's Tale. In these productions, designed to capitalize on the appearance of a notShakespeare play in a Shakespeare series, the visual allusion to Shakespeare sought to produce an active dialectic with memories of what is understood to signify Shakespeare.

This was the strategy of Gregory Doran in his 2011 production for the RSC in the Swan. The performance of the play within a Shakespearean theatre by the Royal Shakespeare Company was further supported by the synchronic casting of the play with Philip Massinger's The City Madam (also in the Swan) and Shakespeare's A Midsummer Night's Dream (in the RST), allowing the play to resonate as a link between Shakespeare and notShakespeare (albeit the venue implied a bias towards the latter). The staging style was familiar from the company's Shakespeare productions, but, as with MokitaGrit and KDC, particularly aimed to evoke Romeo and Juliet. An enormous iron gate separated the two 
lovers and, once again, Luscinda (Leonora) was accompanied by a Duenna while Cardenio pined on the other side of the bars. The Catholic trappings and deployment of coffins added to an aesthetic most regularly associated with Romeo and Juliet since Baz Luhrmann's 1996 film. Such strategies saw Cardenio repeatedly, implicitly and explicitly, aligned with Shakespeare, not least in the incorporation of extra Shakespeare into the text. In giving Fernando the lines, 'Why, you may see him grow into his seat, / And to such wonderous doings bring his horse / As he had been incorpsed with the beast' adapted from Hamlet 4.7.71-4, Doran notes, 'Surely the critics will recognise a line stolen from Hamlet?' (192); but no critic did, suggesting that a Shakespearean frame of interpretation was active at least to the extent that a Shakespearean quotation did not jar.

Reviews of this production concentrated overwhelmingly instead on the reviewers' own impressionistic sense of the play's authorship at the expense of discussion of the production itself. Charles Spencer felt that ' $[\mathrm{t}]$ he second half in particular often has echoes of Shakespeare, with its sudden twists of fate and courtly characters adopting disguises and mixing with peasants in the countryside ... The recognition scenes and hard won forgiveness of the last act recall the late romances, and as in so many Shakespeare plays, a girl assumes the disguise of a boy' (Spencer). Even though the presentation of the shepherds in this production went nowhere near as far as the KDC production in evoking The Winter's Tale, Spencer still read this production through that play, while generic conventions of the early modern drama are identified as Shakespearean. Simon Tavener went further:

Whether or not this Cardenio is derived from something that's authentically Shakespearean or is rather more of a well-constructed later pastiche does not really matter. It delivers a satisfying evening in the theatre. There are elements that echo narrative strands and characters from plays as diverse as Cymbeline and King Lear and overall I found it a close cousin to All's Well That Ends Well. (Tavener) 
Tavener's review is illustrative of Shakespeare standing as a shorthand - there is no explanation of what in the production evoked these different plays, or why this combination of apparently random associations results in a 'satisfying evening'. The likeness of the play to unspecified elements of particular Shakespearean plays stands as its own assertion of value.

Yet even when a reviewer attempted to see a different author, the Shakespeare standard was asserted. Michael Billington found

echoes of Two Gentlemen of Verona. But when Dorotea dons male disguise to pursue Fernando, we are in All's Well That Ends Well country. Meanwhile, poor Cardenio impotently seeks revenge like a Hispanic Hamlet. And the ending, with its double marriage and tide of forgiveness and reconciliation, is straight out of the late romances. (Billington)

Billington constructs his review as a portfolio of intertextual reference. Via the geographical metaphor of a 'country', Cardenio becomes a quixotic knight-errant of a play, journeying to the distant, better-known lands of canonical Shakespeare. Cardenio himself is a 'Hispanic Hamlet', exoticizing Shakespeare with language that might be read as colonial in its imposition onto a new text of dominant interpretive paradigms. Billington is on less stable ground, though, in attempting to identify the 'not-Shakespeare'. Fletcher has an 'eye for a strong dramatic situation', while an aborted wedding 'smacks of Fletcher'; Billington of course does not mean to imply that Shakespeare neither portrays aborted weddings nor can construct good drama. A Fletcher play is almost indistinguishable, in fact, from other notShakespeare: 'Fernando's violation of Dorotea and subsequent guilty evasiveness might have come out of a number of Jacobean plays'. Not only does Billington carefully separate sexual assault from Shakespeare, but not-Shakespeare has an aspect of homogeneity even for an experienced critic. Ultimately, Billington judges the play 'pseudo-Shakespearean' on the 
basis of a negative, the lack of a particular 'blend of the high poetic and the quotidian that is [Shakespeare's] trademark'.

The judgement of the authorship of Cardenio by audiences is based on little more than impression, and it is impossible to judge the quality of the 'Shakespearean' aura to which critics were referring, largely because the collective memory of Shakespeare is heterogeneous. For me, for example, the aura of Shakespearean authenticity was skewed by my recognition of the actor Alex Hassell, playing Fernando, from his previous appearance as Edward de Vere in Mark Rylance's anti-Stratfordian play I Am Shakespeare, prompting sense memories of a challenge to Shakespeare rather than an affinity. Nonetheless, the ghosting of Doran's Cardenio by Shakespeare - in textual quotations, recycled costumes, set, the theatre itself, actors, music, and house directorial style, let alone the extensive publicity surrounding the authorship question - all played into the Shakespearean aura which this production aimed to create. Carlson speaks of the 'Haunted Production' in which

a theatregoer returns to a long-running production many months or even years after first seeing it, when one may have the sometimes uncanny experience ... of seeing a production in which everything-costumes, scenery, lighting, even basic blocking and gestures-has remained essentially the same but with a totally new set of bodies in place. (98)

While he talks specifically of long-running productions of the kind found on Broadway or in the West End, the retention of Shakespearean elements within a house style such as the RSC's arguably has a similar effect, encouraging reviewers to speak of their familiarity with what is presented as a result of their long-time subliminal conditioning by what, at the RSC, constitutes Shakespeare. What is clear for the reviewers of this production is that Shakespeare 
was undeniably present, whether as a standard for the production to (fail to) reach or as an interpretive paradigm through which to articulate perspectives on the production.

The situation of the production within a collective Shakespearean memory is the problem that affects any production of not-Shakespeare, even those that are not subject to a question of authorship. For a company such as the RSC, Shakespeare is explicitly a necessary precondition, the more so because of the constant repetition and reinforcement of the Shakespearean element. Peter Holland cautions that 'Shakespeare performance critics are themselves members of ... audiences, trying to make into memory the experience of theatre or film but encountering the crucial uncontrollability of memory and the inevitable torrent of forgetfulness' (4), but Carlson notes that Shakespeare is Shakespeare because he is what has not been forgotten: 'Our critical and theoretical memories are haunted by Hamlet, as Shakespeare in general and Hamlet in particular have occupied a central position in critical thought for the past two centuries' (79). Recognition and familiarity are consequences of not forgetting, and the predominance of Shakespeare in production, criticism, and education ensures that Shakespeare remains the default and is acknowledged as a form of familiarity; not-Shakespeare, by extension, becomes what is unfamiliar, forgotten, and unseen. Only in the more recent attempts to identify recurrent features of not-Shakespeare has this been redressed, and I turn now to the 'Jacobean'.

\section{Not-Shakespeare as Not Shakespeare}

Susan Bennett's important definition of the 'Jacobean' can be summarized briefly.

[The Jacobean] come[s] into use for many kinds of cultural production (deriving from any number of historical moments) which share some of the values that characterized the primary generic forms of Jacobean drama, the city comedy and the revenge tragedy. ... [T] $]$ he Jacobean is an aesthetic that attempts to mask not only class, but 
issues of gender, race and sexuality. Despite such an attempt, its recitation often exposes rather than veils the instability of these identities, and does so in order to challenge notions of cultural capital in the contemporary. Its aesthetic use most commonly, however, is as a denotation of (moral) decay, excess and violence deficiencies we also find in our contemporary moment and for which this past can apparently give expression and meaning. (81-2)

The Jacobean is a particular facet of, rather than a synonym for, not-Shakespeare, defined specifically by its excess in the presentation of sex and violence, its black humour, its insistence on contemporaneity, and its rootedness primarily in the modern performance of Jacobean tragedy, most commonly The Changeling, The Duchess of Malfi, The Revenger's Tragedy, Women Beware Women, and The White Devil, all of which rank among those notShakespeare plays Jeremy Lopez demonstrates are most regularly revived (225). Bennett's recognition of the aesthetic most commonly attached to these plays in contemporary performance - excess, transgression, violence, sexual promiscuity - rather than the chronological framework means that other plays sharing these features are also referred to regularly as Jacobean, including the Elizabethan Arden of Faversham (RSC, 'Summer '14' 10) and Edward II (Aebischer 20-65) and the Caroline 'Tis Pity She's a Whore, bringing the most prominent not-Shakespeare plays more consistently into line with an antithetical position. As these studies have shown, the 'Jacobean' exists in discourse entirely as an 'other' to Shakespeare, and is perhaps the only aesthetic or interpretive paradigm in the contemporary performance of early modern drama to rival the 'Shakespearean'.

Bennett defines the Jacobean explicitly in relation to Shakespeare as an aesthetic that aims for a radical contemporaneity in opposition to a perceived understanding of Shakespeare as conservative, traditional heritage. Jenny Sager extends this definition, suggesting that in 'both performance and criticism, "not-Shakespeare" continues to position itself as a site of 
radicalism, a place to break new ground, in response to a Shakespeare who continues to be regarded as the epitome of virtuous respectability' (3). Within this model, contemporary productions of not-Shakespeare adopt a transgressive presentism that implicitly forces Shakespeare into an historical paradigm. The old adage of 'It's not Shakespeare', therefore, applied to-a controversial production such as Rupert Goold's 2011 Las Vegas-set The Merchant of Venice, has the dual meanings of 'It is not true to a Shakespearean aesthetic' and 'It is an example of not-Shakespeare', insofar as not-Shakespeare can be defined with contemporary chic. In this sense, it is theoretically possible that Shakespeare can be notShakespeare: for instance, Kim Solga discusses Titus Andronicus alongside A Woman Killed with Kindness, The Duchess of Malfi, and Women Beware Women in her study of Violence Against Women in Early Modern Performance, a book whose subject matter aligns with Bennett's definition of the Jacobean. That Titus Andronicus's subject matter and excesses led to its exclusion from the Shakespeare canon for many decades indicates the potential ramifications of slippage between the Shakespeare and not-Shakespeare aesthetics; and tellingly, productions of Titus (most famously Julie Taymor's 1999 film) adopt many of the counter-culture elements (body piercings and tattoos for actors, nudity, gore, additional suggestions of incest etc.) that define contemporary Jacobean productions.

Not-Shakespeare is defined, then, by both its similarity to and fundamental differences from an idealized Shakespeare aesthetic. The 2014-15 winter season in the SWP at Shakespeare's Globe gives as good an indication of any of how pervasively Shakespeare's ghost haunts the plays of his contemporaries. This season, 'Love by Candlelight', included a revival of the successful 2014 production of Francis Beaumont's The Knight of the Burning Pestle and new productions of Thomas Middleton and William Rowley's The Changeling, John Ford's 'Tis Pity She's a Whore, and Ford's rarely performed The Broken Heart. The productions featured a large proportion of cross-casting across the season (though the 
productions were performed consecutively) and were performed in a space that, physically, appears to kneel before the larger Globe theatre at the bottom of whose foyer it resides, and which was again in 2015 reserved primarily for Shakespeare. Yet despite the frisson of excitement over a new, alternative venue at Shakespeare's Globe, the productions were often evaluated through a Shakespearean lens. Responses to 'Tis Pity repeatedly evoke Romeo and Juliet:

It's Romeo and Juliet,' [director Michael] Longhurst says, 'but they're brother and sister - it's always too much. (Jays)

For those unfamiliar with the play, imagine Romeo and Juliet were brother and sister-that would certainly change the tone of Shakespeare's greatest romance, would it not? (Vallely)

Then, naked, making love under crisp white sheets, curled seductively around their bodies, their after-play is so erotic, so sensual, so electric that they make Romeo and Juliet seem like mere hand-holders. (Collins)

The play is like a grotesque distorted echo of Romeo and Juliet. There's friar confidant [sic]; a prurient nurse figure; there's even a Mercutio-like death, consciously travestied in that it befalls a vain, booming, insecure buffoon (superb James Garnon). (Taylor)

Even though it is a critical commonplace that Ford's love tragedy evokes and perhaps even parodies Shakespeare's, the purpose behind these comparisons is not intertextual dissection, but the easy evocation of Shakespeare to illustrate precisely what this play is and is not. For Michael Longhurst, the production's director, Shakespeare provides the starting point for an understanding and unpacking of the play's potential, suggesting that even though the text is 
by Ford, the play begins in the director's mind as Shakespearean. Given that the Globe was exploring the canon of Ford in this season, it is notable that the director had immediate recourse to Shakespeare. There is also an indication of excess here; the 'brother and sister' angle makes the story 'always too much' (my emphasis), evoking the excess of Bennett's Jacobean.

The comparisons also make implicit critical assumptions about Shakespeare's play. That Romeo and Juliet is 'Shakespeare's greatest romance' is debatable at best, but it points to a superficial set of impressions of that play in the popular cultural consciousness. The faux innuendo of 'change the tone... would it not?' moves the set of connotations into the realm of the sordid, the nudge-wink of innuendo reminding the audience of what we really think about the Jacobean drama, supported in the third quotation as the reviewer indulges in his own sexual fantasy involving Giovanni and Annabella. My experience of watching this scene was very different from this reviewer's: I saw an aggressively one-sided sexual encounter (Giovanni thrusting atop an unmoving and, from the pit, near-invisible Annabella) and an exploitative, reductive reduction of the two characters' sexuality to soft pornography. On the other hand, any number of Romeo and Juliets have stripped their leads appropriately naked for a post-coital scene; so quite which reading of Romeo and Juliet turns them into 'hand holders' is unclear. The overriding message of 'Romeo and Juliet, but hotter/more perverse' is jointly set forward by both production and reviewer, all the while foisting a conservative prudishness on Shakespeare and a hedonistic sexuality on Ford. The idea that this is a 'grotesque, distorted echo' of Romeo and Juliet perhaps best sums up the situation of Ford's play within an emphatically not-Shakespeare framework - it is like, but not. The comparison of nurses, 'travestied' Mercutio-figures, and Friars all tends towards what Gordon McMullan identifies, using the example of The Changeling, as a 'stain of ugliness' that 'is the embodiment of what criticism, mourning for both Elizabeth and Shakespeare, has misnamed 
"the decadence of the drama"” (228), seeing the Jacobean Ford as both dependent on and deviant from Shakespeare. In this dependent deviance, not-Shakespeare rears its head most explicitly, legitimizing the new production within a Shakespearean framework while at the same time ensuring the taxonomic difference between Shakespeare and not, to the detriment of both.

While 'Tis Pity bore the brunt of the Shakespeare comparisons, the other productions in the Love by Candlelight season were not immune. In The Broken Heart, Amy Morgan 'rav[ed' like a distracted memory of Hamlet's Ophelia' (Cavendish 'The Broken Heart') and The Evening Standard declared, 'It takes place in Sparta, but feels like a hybrid of Ibsen, Game of Thrones and one of Shakespeare's so-called "problem plays"' (Hitchings). It is important to note that-the more specific references always tend towards the most familiar of plays and characters, continuing to reinforce the Shakespearean 'centre', while references to those plays at the fringes of the canon (such as the 'problem plays') are generic and vague. John Nathan typifies the prejudice:

As if Shakespeare wasn't a hard enough act to follow, the Jacobean playwright now has to follow a performance by the all-conquering Mark Rylance who starred in the previous production on the Globe's interior candle-lit stage. And as always with Shakespeare's near contemporaries, revivals show up the gap between them and the Bard. (Nathan)

As always, remarks Nathan, while continuing to evoke the 'Jacobean' to describe a Caroline play. The surety with which Nathan asserts the 'gap' between Shakespeare and notShakespeare reaffirms that one of the purposes of reviving not-Shakespeare is to demonstrate Shakespeare's superiority. The review shows awareness that there is a problem: Shakespeare is a hard act to follow, especially if the production is doomed to comparative failure. Reviews 
of The Changeling, however, made no mention of Shakespeare. It is important to note that Shakespeare is invoked most often to describe the unfamiliar: he is the point of reference when encountering the new, the necessary memory evoked because of his ubiquity when there is no other shared memory. For The Changeling, a much more familiar staple of the Jacobean drama, references were instead to the bloody excess of the Jacobean itself.

'Tis Pity She's a Whore is perhaps marked both by its novelty and by its otherness to Shakespeare, meaning that, even away from the main Shakespeare institutions, the play brings together a frisson of being not-Shakespeare with a counter-cultural tendency. The Guardian positioned the play as 'Romeo and Juliet meets Quentin Tarantino' in 2011, following a production at West Yorkshire Playhouse that caused some controversy after Catholics objected to the production's poster, featuring the word 'Whore' next to an image of the Madonna, being prominently displayed during Easter weekend (Miller). The very fact that the media managed to create a headline story out of this was indicative of the play's and production's perceived role as a trouble-stirrer, from the title to the provocative Catholic imagery. If the Shakespearean implicitly supports mainstream institutions, then notShakespeare, in the form of 'Tis Pity's Jacobean excesses, implicitly challenges them. Bennett identifies-'Tis Pity as 'a text that compulsively dramatizes taboo' (172), and quotes David Edelstein's description of it as 'a play in which individuals, swollen like monsters, rebel against the universe's moral laws and receive a terrible punishment' (102). NotShakespeare transgresses against Shakespeare and against 'normative' (read Shakespearean) codes of moral conduct.

Cheek by Jowl's production of 'Tis Pity typifies some of these ideas. Here, as opposed to the more conservatively staged 'Shakespearean' Globe production, reviews made no reference to Romeo and Juliet. Instead the production, which toured to theatres less explicitly ghosted by Shakespeare, was characterized in terms of its pop-culture references, 
extreme cutting, and dynamic choreography. The Arts Desk saw the production as a 'popculture remix', making reference to Twilight, Lisbeth Salander, Lolita, Cathy and Heathcliff, and MTV; and read the allusiveness of the Jacobean as essential: 'Our gothic-obsessed teen culture of vampires and virgins, where blood is traded as erotic currency, is revealed here as no new phenomenon, but rather the MTV ghost of a routine whose historical beat yet pumps on in Ford's tragedy' (Coghlan). For The Independent, Annabella 'danc[es] wildly on her bed like a would-be rock chick. She's a wafer-thin adolescent: leggings, hot pants, punky, halfshaved haircut' (Bassett). For Dominic Cavendish, the play is 'one of the late stragglers of the Jacobean gore-fest era ... This twisted tale of unbridled sibling passion could be the stuff of Jeremy Kyle or Jerry Springer' ('Tis Pity'). The reviews, still dependent on memory, here seek to tap into different areas of cultural zeitgeist, exorcising Shakespeare by attempting to capture a deliberately eclectic network of interests gathered by the representation of a contemporary teenaged girl.

Cheek by Jowl's production aimed to connect with a young audience, and its set - an unusually detailed one for the company - positioned the whole of the action within a teenager's bedroom, walls decorated with posters and a door leading to her private bathroom. Annabella's bed, dominating the stage, became the locus of a series of illicit incursions as men invaded her private space, a theoretically shut-off world of sexual awakening, fantasy, sleep, exposure, and escape. The depiction of the invasion of Annabella's physical and mental space by the men who wished to position her self-expression as whorish succeeded in opening a space gendered female, rendered sexual, and aligned with non-Shakespearean, antihigh culture modes of expression; to strengthen this emphasis, the production also ended with her death, denying Giovanni his self-justification and the Cardinal his definition of Annabella as a whore. Yet this inversion occurred within the context of a company whose name is a Shakespearean quotation, which is renowned for its performance of the classical repertoire, 
and in a theatre (the Barbican, where the show was reviewed) that, before and since though not at the time, has been the London base of the RSC. In a fine irony, then, not-Shakespeare and the Jacobean became a part of the Shakespeare establishment, allowing Cheek by Jowl in this production to offer something transgressive.

The idea that the production was 'thoroughly modern' pervaded reviews, implying that reviewers saw this contemporaneity as an unusual feature in an early modern notShakespeare play (Bassett). Cheek by Jowl's own publicity describes 'Tis Pity as a 'vivid and violent Jacobean tragedy [that] shows a brother and sister's passionate descent into hell. Incest, religion and corrupt morality collide in this "sexy, stylish production" (The Times), making this play as shocking and controversial today as it was almost four hundred years ago' ('Tis Pity'). The hallmarks of the Jacobean are all present and correct, and they form an important part of creating the necessary sense of frisson to attract a new audience to the production. To be modern is often to create a sense of controversy, as Aebischer and Prince note in their discussion of the RSC's 2005 Gunpowder season featuring 'the banned-in-itsown-time Thomas More; the allegedly treasonous Sejanus; the comedy about making way for the young by euthanizing the old; A New Way to Please You; and Massinger's Middle East terrorism play, lightly retitled as Believe What You Will rather than Believe As You List' (5). Despite the hackneyed debates about the 'controversy' of plays such as The Merchant of Venice or The Taming of the Shrew, the collective memory that renders Shakespeare and pseudo-Shakespeare comfortingly familiar neuters the potential for genuine shock in contemporary performance. It is for this reason that companies seem to turn to notShakespeare.

\section{It's good, but it's not Shakespeare}


Shared cultural reference is part of the communication of critique, and interpretive skill is deferred to that which can be justified by experience. The pattern is, of course, selfreinforcing. Just as Shakespearean authorship studies are based on the establishment of a Shakespearean profile made up of those linguistic features that recur most frequently, so productions of unfamiliar not-Shakespeare plays are judged against a standard that adheres most closely to a Shakespearean standard familiar to as many as possible. Reviewers' use of Shakespeare, either to support what a production is or criticize what it isn't, acts to shore up the sense of what Shakespeare is. Yet, as this too-brief analysis suggests, not-Shakespeare is a fundamental part of the Shakespeare performance aesthetic in two key respects.

First, the lazy subsuming of not-Shakespeare within Shakespeare - of which critics are as guilty as theatres - means that not-Shakespeare production is frequently spoken of as Shakespeare and evaluated through a Shakespearean lens. As productions of plays by Ford, Marlowe, Webster, Middleton et al. proliferate, so our interpretive lens for all early modern drama develops and becomes part of the collective, mainstream memory. This memory is dependent on the continual production and revival of the early modern dramatic canon. It is improbable that such memory will ever not be dominated by Shakespeare, but the development of particular models of performance for not-Shakespeare will allow the modern stage to develop a vocabulary of performance for early modern drama that shifts away from the all-pervasive Shakespeare filter. Given time, the Jacobean may haunt Shakespeare as much as Shakespeare haunts the Jacobean.

Second, and perhaps more important, the Shakespeare company that seeks to be modern or contemporary turns to 'Not-Shakespeare, Our Contemporary' precisely to make critical, political, or aesthetic interventions in models of 'Shakespearean' performance that allow a production to be categorized as modern. In other words, a belief is emerging that even Shakespeare productions have to be to some extent 'not-Shakespeare' in order to generate the 
transgressive effect that not-Shakespeare inherently carries. Paradoxically, in a postmodern climate that favours cynicism, intertextuality, allusiveness, frankness, and speed, the notShakespeare aesthetic has become a culturally dominant model, as is implicit in The Arts Desk's list of current trends that it could associate with Cheek by Jowl's 'Tis Pity.

Shakespeare, in order to maintain its cultural dominance, is under increasing pressure to adopt the radical chic of not-Shakespeare. Fittingly, with the opening of the Sam Wanamaker Playhouse, the performance of Shakespeare in both conservative and radical paradigms is increasingly foregrounding the Jacobean, suggesting that, in the future, not-Shakespeare and Shakespeare may become ever more difficult to tell apart.

\section{Works Cited}

Addenbrooke, Barrie. 'Double Falsehood'. Double Falsehood. Programme. London, 2010. Print.

Aebischer, Pascale. Screening Early Modern Drama: Beyond Shakespeare. Cambridge: Cambridge UP, 2013. Print.

Aebischer, Pascale, and Kathryn Prince, eds. Performing Early Modern Drama Today Cambridge: Cambridge UP, 2012. Print.

Aebischer, Pascale, and Kathryn Prince. Introduction'. Aebischer and Prince 1-16.

Bassett, Kate. ' Tis Pity She's a Whore, Silk Street Theatre, Barbican, London The Bomb A Partial History, Tricycle Theatre,London, In Basildon, Royal Court, London'. The Independent 26 February 2012. Web. 26 April 2015. 
Bennett, Susan. Performing Nostalgia: Shifting Shakespeare and the Contemporary Past. London: Routledge, 1996. Print.

Billington, Michael. 'Cardenio - review'. The Guardian 28 April 2011. Web. 26 April 2015.

Brown, Karin. 'Professional Productions of Early Modern Drama in the UK and USA, 19602010'. Aebischer and Prince 178-217.

Carlson, Marvin. The Haunted Stage: The Theatre as Memory Machine. Ann Arbor: U of Michigan P, 2003. Print.

Cavendish, Dominic. “'Tis Pity She's a Whore, Cheek by Jowl, Barbican, review'. The Telegraph 22 February 2012. Web. 26 April 2015.

Cavendish, Dominic. 'The Broken Heart, Sam Wanamaker Playhouse, review: valiant but doomed'. The Telegraph 22 March 2015. Web. 26 April 2015.

Coghlan, Alexandra. 'Tis Pity She's A Whore, Barbican Theatre'. The Arts Desk 22 Feb 2012. Web. 26 April 2015.

Collins, Stephen. 'REVIEW: 'Tis Pity She's A Whore, Sam Wannamaker Theatre'. British Theatre Guide 6 November 2014. Web. 26 April 2015.

Doran, Gregory. Shakespeare's Lost Play: In Search of Cardenio. London: Nick Hern, 2012. Print.

Farley-Hills, David. Shakespeare and the Rival Playwrights, 1600-1606. London: Routledge, 1990. Print.

Hammond, Brean, ed. Double Falsehood. London: Arden Shakespeare, 2010. Print. 
Heijes, Coen. "“Thus play I in one person many people": The Art and Craft of Doubling in the Boyd History Cycle'. Shakespeare 6.1 (2010): 52-73. Print.

Hitchings, Henry. 'The Broken Heart, Sam Wanamaker Playhouse - theatre review: Spartan tale of love and grief'. London Evening Standard 5 April 2015. Web. 26 April 2015.

Holland, Peter. 'Introduction'. Shakespeare, Memory and Performance. Ed. Peter Holland. Cambridge: Cambridge UP, 2006. 1-19. Print.

'Home'. Digital Renaissance Editions. University of Victoria, n.d. Web. 26 April 2015.

Jays, David. 'Carnage by candlelight: Michael Longhurst on 'Tis Pity She's a Whore'. The Guardian 24 October 2014.” Web. 26 April 2015.

Kirwan, Peter. Shakespeare and the Idea of Apocrypha. Cambridge: Cambridge UP, 2015. Print.

Kirwan, Peter. 'The Roared-at Boys? Repertory casting and gender politics in the RSC's 2014 Swan season'. Shakespeare, 11.3 (2015): 247-61. Print.

Lopez, Jeremy. 'Performance of Early Modern Plays by Amateur and Student Groups Since 1887’. Aebischer and Prince 225-27.

McMullan, Gordon. 'The Changeling and the Dynamics of Ugliness'. The Cambridge Companion to English Renaissance Tragedy. Ed. Emma Smith and Gareth A. Sullivan Jr. Cambridge: Cambridge UP, 2010. 225-35. Print.

Miller, Joe. 'Maverick director talks incest, posters and "whores” at West Yorkshire Playhouse'. The Guardian 21 April 2011. Web. 26 April 2015.

Nathan, John. 'The Broken Heart, Sam Wanamaker Playhouse, review: Ghoulish tragedy but with a sardonic touch'. The Independent 19 March 2015. Web. 26 April 2015. 
National Theatre. 'National Theatre Financial Statements 2013-14'. National Theatre. Web. 26 April 2015.

RSC 'Summer '14'. Brochure, n.d. Print.

Sager, Jenny. 'Not Shakespeare: Early Modern Drama and Film'. Shakespeare Bulletin 32.1 (2014): 1-10. Print.

Samuel, Raphael. Theatres of Memory, Volume 1: Past and Present in Contemporary

Culture. London: Verso, 1994. Print.

Smith, Peter J. 'The Jew of Malta, by Christopher Marlowe'. Times Higher Education 2 April 2015. Web. 26 April 2015.

Solga, Kim. Violence Against Women in Early Modern Performance. Basingstoke: Palgrave Macmillan, 2009. Print.

Spencer, Charles. 'Cardenio, RSC, Stratford-upon-avon, review.'.The Telegraph 28 April 2011. Web. 26 April 2015.

Tavener, Simon. 'Cardenio (RSC, Stratford)'. What's On Stage 28 April 2011. Web. 26 April 2015.

Taylor, Paul. 'Tis Pity She's a Whore, Sam Wanamaker Playhouse, review: The tragedy of sibling incest written in the early 1630s by John Ford'. The Independent 6 November 2014. Web. 26 April 2015.

‘'Tis Pity She's a Whore'. Cheek by Jowl, Cheek by Jowl, 2014. Web. 26 April 2015.

Vallely, Neil. 'Embracing Candlelight: Neil Vallelly reviews 'Tis Pity She's a Whore'.

Shakespeare’s Globe Blog 6 November 2014. Web. 26 April 2015. 